MarTa Josefa Pérez Winter de Tamburini

\title{
LECTURA DE TIERRA DE LOS HOMBRES
}

Saint-Exupéry nos ofrece en Tierra de los hombres, libro dedicado a "Henri Guillaument, mon camarade", un mensaje que es el hilo de Ariadna que liga los diversos episodios del libro en un ramillete cerrado de siete capítulos de desigual extensión: "La Línea", "Los camaradas", "El avión", "El avión y el planeta", "Oasis", "En el desierto", "En el centro del desierto".

¿Cual es ese mensaje? Una golondrina no hace la primavera; una fe ingenua en la dignidad humana no basta para formar al hombre. Nadie lo sabía mejor que Saint-Exupéry que busco durante años definir esta dignidad y el sentido de la palabra "hombre". Usadas, pulidas como guijarros, las expresiones "dignidad humana", "hombre", "búsqueda de la felicidad", "conciencia de la humanidad", estaban vacías de sentido, limpiadas por el flujo y reflujo incesantes de los debates ideológicos, de las charlas humanitarias. Una cosa es clara: Rousseau declara al comienzo del Contrato social: "El hombre nacio libre, pero está en todas partes encadenado". Estas rejas son siempre tan actuales como bajo el Antiguo Régimen, pero el hombre no nace libre ni esclavo. El hombre no nace hombre, nace niño. El individuo "es". El hombre "llega a ser": lentamente, paso a paso, en el transcurso de un combate incesante, por el dominio de si.

Si no fuera asi, si la Tierra fuera hospitalaria y el hombre (el hombre natural de Rousseau) esencialmente bueno, nuestros problemas se resolverían por si mismos.

La vida perdería su tensión permanente y el mundo se convertiría en un jardín del Edén, parecido a las islas polinésicas donde los habitantes no tienen más que tender la mano para recoger las frutas que penden de los árboles. Pero vastas extensiones de nuestro planeta son inhóspitas, a veces inhabitables. La existencia humana no se desenvuelve sin esfuerzo a través de una planicie. Es una ascensión por una pendiente resbaladiza, sin piedad para aquel cuyo esfuerzo cede. Y en esta 
lucha ascensional, el individuo permanece como una tabla a la deriva, una cifra en un océano de cifras, un átomo en un hormiguero de átomos.

Y este mensaje lo expresa desde las primeras líneas del libro: "La tierra nos informa más ampliamente acerca de nosotros que todos los libros. Porque nos resiste. El hombre se descubre cuando se mide con el obstáculo". En estas tres oraciones, que resuenan como golpes de martillo, Saint- Exupéry condensa toda la sabiduria que conquist 6 .

La verdadera calidad del hombre no es una cosa que se da de una vez para siempre cuando nacemos, sino hay que adquirirla. El hombre es lo que es, no en virtud de lo que hereda sino de lo que hace, de lo que crea.

Ultimo testimonio de Saint-Exupery sobre la Línea es este libro. Pero testimonio posterior a la accion, testimonio reflexivo, que lleva al autor al octavo y último capítulo, a su primera escala espiritual: "Los hombres".

Para llegar a ella el piloto y sus camaradas obedecen a una "vocación soberana" y aprenden a utilizar el avión (el útil) con la satisfacción del iniciado y el orgullo de la consagración.

En sus ritos de iniciación también viven el sentido de fraternidad al descubrir el valioso bagaje de las relaciones humanas. "Viento, arena, estrellas. Un estilo duro propio de ermitanos. Pero sobre esa capa mal iluminada, seis o siete hombres que no poseen ya nada en el mundo, fuera de sus recuerdos, se reparten riquezas invisibles". Invisibles riquezas que Saint Exupéry saca a relucir con vistas a un comercio cálido.

Y camaradas y avión los ligan a todos los hombres. Porque el individuo no puede vivir solo, como es incapaz de vivir la |rama desgajada del árbol o privada de su savia.

Es ese mismo avión el que los lleva a conocer el verdadero rostro del planeta que no es aquel de los caminos que unen una ciudad con otra sino éste de la huella de lava de un mundo mineral, de la cima, de los tres árboles, de aquel arroyo y de esta granja.

También son iniciados en los signos y descubren en el color del cielo, en el rastro del viento, en la presencia insolita de dos libélulas en un oasis, el anuncio de tempestades, y así comprenden el "lenguaje secreto".

Parten a buscar la vida haciendo lo que ninguna bestia haría, como Guillaumet perdido en los Andes o Saint-Exupery en el desierto de Libia, sufriendo, con el estertor de la agonía, pero caminando siempre, para sus mujeres que creen que ellos caminan; para sus camaradas que están seguros que ellos caminan; apoyăndose en su cuerpo que no es más que "un buen átil... 
un servidor"; descubriendo, en la aurora de la salvación, el valor del agua que no es "necesaria a la vida sino la vida misma", y definiendo al hombre con un orgullo admirable.

Ahora bien, pero la moral de todo esto no se sitúa esencialmente en estas demostraciones épicas de heroísmo humano. Tierra de los hombres no fue concebida como un libro de aventuras que relata las hazañas de aviadores, de soldados o de beduinos. Su tema central se resume en una metáfora que no es deportiva ni guerrera sino artesanal: "Es una cualidad que no tiene nombre. Es la cualidad del carpintero que se instala de igual a igual frente a su trozo de madera, lo palpa, lo mide $y$, lejos de tratarlo a la ligera, resume todas sus virtudes". Y el modelo de esto que Saint-Exupéry considera como debe ser el summun del comportamiento humano, no es solamente Guillaumet buscando penosamente salvación sino también el viejo jardinero que dice en su lecho de muerte: "Sabe... a veces sudaba cuando cavaba. Mi reumatismo me endureció la pierna y yo maldecia esa esclavitud. Pues bien, ahora quisiera cavar, cavar en la tierra. iQue hermoso es cavar! iQué libre es uno cuando cava! Y despues: ¿quién va a podar mis árboles?".

He aqui la moral universal que extrae Saint-Exupéry: "Ser hombre es, precisamente, ser responsable". El jardinero de sus árboles, el padre de su familia, el carpintero de su oficio, el escultor de su arte, el marino de su barco.

También estos aviadores gustan las alegrias de la verdadera camaradería que no es, jamás, sensiblería sino sentimiento puro.

Sufren pero aceptan la desaparición de sus camaradas porque está en el orden del oficio.

Debe haber esperanzas para todos los hombres de conocer estas|"alegrías tan cálidas": Porque los hombres son parecidos a los de la Aeropostal, pero faltos de ocasiones, faltos de un terreno favorable, faltos de una "religión exigente", ellos no saben que tienen hambre y se duermen.

Se duermen en los bares a la hora en que, en Dakar, los mecánicos se despiertan; a la hora en que Mermoz decola para atravesar el Atlántico Sur; a la hora en que, en España, un contador de Barcelona se levanta para hacer la guerra.

Y concluye Tierra de los hombres con un conmovedor llamado: el burócrata de Barcelona hace la guerra no por convicción política. El hombre se enroló despues de haber sabido que un amigo se murió en combate.

Todo acto inspirado por el amor lleva a la fe.

Por el amor de un hombre, por el amor de una sonrisa, por el amor de un árbol, por el amor de un poema, por el 
amor de una sola nota, por el amor del avión como por el del carro, es necesario decubrir las vocaciones a fin de no dejar en nosotros un Mozart asesinado. 